\title{
Electoral behaviour of young people at regional elections
}

\author{
Olga Parfenova ${ }^{1}$, Matryona Okorokova $^{1}$, and Nurgun Grigoriev ${ }^{1, *}$ \\ ${ }^{1}$ North-Eastern Federal University, 677027, 58 Belinsky str., Yakutsk, Russia
}

\begin{abstract}
Young people as a social institution contribute to political socialization, the scientific nature of political consciousness and the maturity of political culture, the formation of interests and the acquisition of skills for political participation, including the electoral one. This research considers the problem of electoral behavior of young people on the example of regional elections based on the ideas of social partnership between the state and youth. On the basis of the research of electoral behavior of young people at the regional level elections, the theoretical and methodological foundations of political research of this problem, mechanisms for improving the quality of political participation are defined, the main components of young people's readiness for electoral activities on the basis of social partnership technologies combined with well-built state protectionism are also identified.
\end{abstract}

The evolution of the Russian political system affects the appearance of the electoral space in the state. The return of direct elections of heads of constituent entities of Russian Federation in 2012, the liberalization of electoral legislation - introduce elements of competition and uncertainty in elections of various levels in the regions. The new cycle of the political process promotes the activation of various actors and interest groups in the regions, which gives dynamics to their socio-economic development. The electoral system of modern Russia is a constant object of reforming the state with each new formation of the political cycle because the institution develops a system of executive and legislative authorities. The non-linear nature of the evolution of Russia's electoral system is an important factor in the development of electoral processes and electoral competition in the regions. Unlike federal elections, electoral campaigns at the regional and municipal levels are relatively competitive. The return of direct elections of the heads of subjects restored the dynamics of the political process, the increase in the importance of political technologists during the elections. At the municipal level, factors of the rivalry strengthen the position of local self-government bodies, which are the form of public authority and are separated from public authorities.

Political culture includes such form as an electoral culture. It is generally disclosed through the activity of voters, awareness of their participation in the electoral process and the meaningfulness of the choice. According to the researchers, in the electoral culture, it is possible to identify certain aspects that characterize it in the broader concept of political

\footnotetext{
* Corresponding author: nagrigoriev@ mail.ru
} 
culture. Thus, an electoral culture includes the psychological orientations of individuals, their groups and societies associated with the existence of an electoral process. Also, an electoral culture, unlike other varieties of political culture, can not exist outside the legal framework. In addition, this type of culture covers only those orientations of subjects of the electoral process that are connected with public policy. The phenomenon of electoral culture involves practically every member of society in the sphere of politics [1].

The political culture of the youth is, of course, correlated with the general political culture. At the same time, it can also act in the form of such models of electoral behavior as: "activist" model, model of "fluctuating preferences" and "absenteeist model". The selective culture of the youth includes the psychological orientations of individuals, their groups and societies, connected with the existence of an electoral process.

To identify and strengthen the channels for interaction between the authorities and civil society, it is necessary to study the electoral behavior of young people during the election period. The building of a civil society and the development of a democratic culture are impossible without an increase in the civic and political activity of young people, without the assimilation by young people of a system of democratic norms and values, of complex moral and legal political education. Therefore, the task of society is to create conditions for the development and self-development of young people, to improve the level of its electoral culture, the formation of special knowledge necessary and sufficient for the implementation of electoral activities. The level of political activity of young people varies depending on the format of elections. Elections of federal significance for young people are of great interest, rather than regional and municipal levels. In this regard, this study is becoming more relevant.

Conceptually, the role of political behavior and socialization of individuals within the framework of political culture was considered in their works by American researchers G. Almond, S. Verba [2], R. Hess and J. Thorne [3], D. Easton and J. Dennis [4]. Political preferences are part of the political culture of the social group and express, according to the classical concept of G. Almond and S. Verba, a psychological orientation towards social subjects, that is, first of all the attitude to the political system, to various political institutions and the individual's own role in the system. Assimilation of young people and their compliance with the social norms of society, its active activities aimed at justifying expectations about themselves and on the very transformation of the social environment as part of political socialization are considered by S.N. Chirun [5]. The phenomena of electoral culture in the sphere of politics were studied by A.I. Verevkin [6]. Questions of the methodology for studying electoral behavior in various regions of Russia can be found in the works of V.V. Borodin, A.V. Shemelina [7], E.Yu. Meleshkina [8], I.V. Malashenko [9].

The main approach to studying the electoral behavior of young people is the interdisciplinary approach, which makes it possible to obtain an objective analysis of the research problem posed:

- socio-economic approach - determining the position, place and prospects of the youth in the life of society, the quality of life, which affect the degree of electoral activity;

- political and legal approach - analysis of state youth policy and legislation at the regional level, which involves analysis of the content, direction of its activities, consideration of the youth as not only an object, but also a subject of youth policy, participation of young people in political processes (primarily in the electoral process), but an assessment of their implementation in the region and the extent to which it meets the needs and desires of young people;

- Institutional approach - analysis of the institutional structure in the region for the implementation of the youth policy and assessment of the relationship between the initiative of the state and civil society; 
- Anthropological approach - understanding of the ongoing life processes through the perception of people themselves, the implementation of laws and policies through the prism of perception by young people themselves;

- Psychological approach is the basis for analyzing the behavior of young people, including political, for example, as individual youth leaders, youth associations and organizations. This method allows studying the psychological motives of youth participation in electoral processes, the images of political leaders in the minds of young people, political technologies and methods of influencing the younger generation, etc. The application of the psychological approach is relevant in studying the basic mechanisms of political behavior of young people, including subjective ones, their temperament, intellectual abilities, individual traits, typical mechanisms of psychological motivations, the role of subconscious factors in the political participation of young people.

As the main research methods can be identified:

- The normative-value method acts as a system of norms, values, ideals that regulate interaction in the political sphere as a whole and involves the correlation of political relations, phenomena, processes with certain normative-value (moral, ethical, religious, ideological) concepts and values of the young generation.

- The system method allows to identify young people as an independent subject of study, in the course of which its individual structural elements are distinguished with their functions. Also, this method involves analysis of the main political institutions that influence young people and determine its political activism, including political parties, social movements, organizations can be viewed from the point of view of studying them as systems with certain functions. The system approach allows to more clearly define the place of youth in the development of society, its most important functions, opportunities in implementing the main activities of the state.

- The structural-functional method allows to analyze the internal structure of the system, the relationship and the role of each component. This approach emphasizes that when the structure and functions change, the system either collapses or turns into another system, its meaning changes.

- The sociological method that allows assessing young people's perception of themselves as an object and subject of politics, to reveal the general motivation, attitudes, values and values of young people for political life, to establish the level and form of their political socialization, activity and mobility, to form a basic list of social, political and other problems among young people through a questionnaire and expert survey.

Regular political elections of different levels have become part of the life of modern society. During the election period, all social groups show their electoral culture in the form of preferences. An important component of the modern electorate is the youth. According to statistical data, the share of the youth relative to the population of Russian Federation is $23 \%$, in the Republic of Sakha (Yakutia) - 26\%. This is a huge force that can influence the development of political processes in the country. Therefore, the study of the electoral behavior of the younger generation, their political preferences, as well as the mechanisms of influence on their electoral activity acquires special attention. For young people as a social group, such characteristics of political culture as the underdevelopment of sociopolitical interests, the dilution of political beliefs and simultaneously the age-appropriate readiness for political mobilization are distinguishing.

Almost a quarter of the population of the Republic of Sakha (Yakutia) are young people. The population of the Republic of Sakha (Yakutia) always demonstrates high selective activity in the Far Eastern region of Russia. North-Eastern Federal University named after M.K. Ammosov is located in the city of Yakutsk in the capital of the Republic (Sakha) Yakutia and is the "forge" of the Far East manpower. The university has 18 departments and more than 17 thousand students. In recent years there has been an all- 
Russian trend, inherent in our university, a certain weakening of the interest of politics on the part of the youth. This raises the justified concern of all social science teachers. In the course of the survey, we also tried to identify the level of interest of students in participating in the forthcoming parliamentary elections. In November 2011, students of the North-Eastern Federal University were surveyed to study political preferences on the eve of elections to the State Duma of the Federal Assembly of the VI convocation. It was planned in advance to compare the results of the poll and the results of the parliamentary elections. The pre-election survey was conducted at five divisions of the university. Students of the Medical institute (100) were questioned in the natural range, the Institute of Foreign Philology and Regional Studies (100), the Faculty of History (100), the Engineering department (100) and the Geological exploration department - in the technical field. Thus, a total of 477 respondents were serveyed. By the time of the survey, not all students had decided on the future political choice. Such a state of student electorate can be explained, in our view, by a number of reasons: inadequate interest and awareness, as well as by the presence of carriers of vacillating and absentee models of political culture. Among the students of the natural-science sphere, $41 \%$ of the respondents were undecided. Quite close indicators on uncertainty were demonstrated by students of humanitarian units $-39 \%$. And the smallest number of vacillators was recorded among technical respondents $-27 \%$. In general, the share of those who did not decide on their political elections in the university was $27 \%$, since the majority of respondents were interviewed in technical units.

Table 1. The pre-election survey 1.

\begin{tabular}{|l|c|c|c|}
\hline \multirow{2}{*}{ Political parties } & \multicolumn{3}{|c|}{ Results of the questionnaire } \\
\cline { 2 - 4 } & Technical directions & Natural directions & $\begin{array}{c}\text { Humanitarian } \\
\text { directions }\end{array}$ \\
\hline United Russia & $87(49 \%)$ & $40(40 \%)$ & $35(35 \%)$ \\
\hline $\begin{array}{l}\text { Communist Party of the } \\
\text { Russian Federation }\end{array}$ & $25(14 \%)$ & $2(2 \%)$ & $9(9 \%)$ \\
\hline $\begin{array}{l}\text { The Liberal Democratic } \\
\text { Party of Russia }\end{array}$ & $7(4 \%)$ & $7(7 \%)$ & $5(5 \%)$ \\
\hline Patriots of Russia & - & - & - \\
\hline Just cause & - & - & $11(11 \%)$ \\
\hline Fair Russia & $10(6 \%)$ & $10(10 \%)$ & $1(1 \%)$ \\
\hline An Apple & - & - & $39(39 \%)$ \\
\hline Uncertain & $48(27 \%)$ & $41(41 \%)$ & - \\
\hline
\end{tabular}

In May 2016, the survey was conducted among students of the North-Eastern Federal University named after M.K. Ammosov on the forthcoming 88 elections to the State Duma of the Federal Assembly of the Russian Federation. Participants in 10 departments of the university were questioned, 4 of them were students (including the Mining Institute, the Institute of Natural Sciences, the Medical Institute, the Institute of Physical Culture and Sports, 169 respondents), 4 humanitarians (financial and economic institute, historical faculty, philological faculty, philology and regional studies - a total of 203 respondents were interviewed), technical - 2 (physic-technical institute, road department - 135 respondents were interviewed). In total 504 respondents were interviewed anonymously. Some of the students at the time of the sociological survey also did not decide on the party choice. Most of all undecided was recorded among students of natural science units - 70 (41.4\%). Also, 75 students of humanitarian units (37\%) failed to indicate their future party choice. The most determined in this issue were students of technical training, among which 37 people doubted. 36\%. A comparative analysis of the data for 2011 and 2016 shows that overall, in all three directions, the overall ratio of undecided respondents remains 
unchanged. The largest number of those who fluctuate according to the results of two surveys is observed in the natural sciences ( $41 \%$ and $41.4 \%)$. The second place is occupied by humanitarian direction (39\% and $37 \%)$. And constantly the least number of hesitants is observed among tech-students $(27 \%$ and $28 \%)$.

Table 2. The pre-election survey 2 .

\begin{tabular}{|l|c|c|c|}
\hline \multirow{2}{*}{\multicolumn{1}{|c|}{ Political parties }} & \multicolumn{3}{|c|}{ Results of the questionnaire } \\
\cline { 2 - 4 } & Technical directions & Natural directions & $\begin{array}{c}\text { Humanitarian } \\
\text { directions }\end{array}$ \\
\hline United Russia & $58(43,9 \%)$ & $83(49,1 \%)$ & $93(45,8 \%)$ \\
\hline $\begin{array}{l}\text { Communist Party of the } \\
\text { Russian Federation }\end{array}$ & $35(26,5 \%)$ & $3(1,8 \%)$ & $8(3,9 \%)$ \\
\hline $\begin{array}{l}\text { The Liberal Democratic } \\
\text { Party of Russia }\end{array}$ & $1(0,8 \%)$ & $4(2,4 \%)$ & $4(2 \%)$ \\
\hline Fair Russia & $1(0,8 \%)$ & $9(5,3 \%)$ & $16(7,9 \%)$ \\
\hline An Apple & - & - & $3(1,5 \%)$ \\
\hline Other parties & - & - & - \\
\hline Uncertain & $37(28 \%)$ & $70(41,4 \%)$ & $75(37 \%)$ \\
\hline
\end{tabular}

The research, conducted by the Department of Political Science in 2011 and 2016 among students of the NEFU to identify political preferences on the eve of parliamentary elections, shows an increase in the proportion of undecided students from $27 \%$ to $36 \%$. Directly during the study, students demonstrated a model of "wavering" electoral culture. To some extent, overcoming this trend in the parliamentary elections. One of the most common stereotypes is the opinion about the passivity of young people in the political process due to objective factors (difficult financial situation, implementation of career development tasks, living conditions, etc.). As it's shown by the research data of regional and municipal elections on the territory of the Republic of Sakha (Yakutia), the electoral activity of young people is lower than in the federal elections. Therefore, in the context of the study, it becomes important to take responsibility of young people for participating in the electoral process, its motives, beliefs, etc., to develop certain mechanisms that enhance its electoral activity.

Thus, the main components of electoral behavior and youth political culture in general can be defined:

Firstly, the intellectual component, which consists in the acquisition by young people of the political knowledge necessary for civilian life in the study of social and humanitarian disciplines, especially political science, sociology and jurisprudence, etc., which is possible within the educational institutions.

Secondly, the value-motivational component testifying to the existence of the formed system of civil relations is expressed in the activities of youth public organizations and movements. Youth is a period of acquiring the necessary knowledge, skills in various spheres of public life and mastering civil procedures, which is due to the presence of pronounced civic feelings. And this is the role of the operational and emotional components of political socialization. As an example, we can mention the skills of participating in elections, rallies, meetings of public organizations, mastering the skills of organizing various public actions, etc.

Thirdly, the strong-willed component is closely connected with the operational and emotional components and can be formed through participation in specific cases. The activities of youth public organizations, student self-government, community organizations, etc., serve as vivid examples. The volitional component characterizes the young man's 
willingness and ability to regulate his own behavior and mobilize his resources in the public interest.

In this connection, using the technologies of social partnership with the leading role of the state has become actual. This approach will give a powerful impetus to solve the problems of political socialization of young people, to make the development of the entire society progressive and conflict-free.

\section{References}

1. V. Petukhov, Free thought, 162, 1 (2011)

2. G. Almond, S. Verba, The civic culture. Political attitudes and democracy in five nations (Boston, 1965)

3. R. Hess, J. Torney, The Development of Political Attitudes in Children (Doubleday and co., New York, 1968)

4. D. Easton., J. Dennis, Children in the Political System: Origins of Political Legitimacy (McGraw-Hill, New York, 1969)

5. S. Chirun, Solation and unification vectors in the social development coordinate system (International Academy of Sciences and Higher Education, London, 2014)

6. A. Verevkin, Bulletin of St. Petersburg State University - Series 6: Philosophy, Culturology, Political Science, Law, International Relations, 4 (2011)

7. V. Borodin, Jurisprudence: Izvestiya Vuzov, 6 (2009)

8. E. Meleshkina, Political process: the main aspects and methods of analysis (All the World, Moscow, 2001)

9. I. Malashenko, Bulletin of the Bryansk State University, 2 (2015) 